\title{
The Profile of a Neurology Clinic and Malnutrition Awareness
}

\section{Bir Nöroloji Kliniğine Yatan Hasta Profili ve Malnütrisyon Farkındalı̆̆ı}

\author{
1 University of Health Sciences Turkey, Bagcilar Training and Research Hospital, Clinic of Neurology, Istanbul, Turkey \\ 2University of Health Sciences Turkey, Prof. Dr. Mazhar Osman Mental and Neurological Diseases Training and Research Hospital, Neurology \\ Clinic, Istanbul, Turkey
}

\begin{abstract}
Objective: Malnutrition is common in patients on admission to hospital, affecting morbidity and mortality. Our study was planned to assess the risk of malnutrition on admission, related comorbidities, and laboratory parameters.

Materials and Methods: All hospitalized patients in our clinic between June 2016 and January 2018 were included in the study. Age, sex, diagnosis and comorbidities were recorded. Laboratory parameters including, creatinine, albumin, C-reactive protein (CRP), lymphocyte count, and lipid profile were studied. Malnutrition risk was calculated using the mini nutritional assessment for patients $\geq 65$ years of age and the Nutrition Risk Screening 2002 for younger patients $(<65$ years of age).

Results: One hundred twenty-eight patients were included in the study. Of these, $45.5 \%$ were women and the mean age of the patients was $61.54 \pm 16.96$ years. The rates of diagnoses were as follows: $68.4 \%$ ischemic stroke, $8 \%$ demyelinating disease, $5.6 \%$ hemorrhagic stroke, $4.3 \%$ central nervous system (CNS) infection, $3.8 \%$ movement disorders, $2.7 \%$ polyneuropathy, $1.8 \%$ epilepsy, $1.6 \%$ pseudotumor cerebri, $1.2 \%$ cranial neuropathy, $1 \%$ dementia, $0.6 \%$ metabolic disorders, and $0.7 \%$ myasthenia gravis. The most common comorbidity was hyperlipidemia. Out of 728 patients, $28.4 \%$ were nutritionally at risk on admission. The malnutrition risk was 30\% in patients with stroke. The malnutrition risks were $19 \%$ for CNS infections, 32\% for movement disorders, $25 \%$ for polyneuropathy, $24 \%$ for demyelinating diseases, $0.8 \%$ for pseudotumor cerebri, and $15 \%$ for epilepsy. Diabetes mellitus was significantly associated with malnutrition risk. Hypoalbuminemia, higher creatinine, and CRP levels were significantly associated with malnutrition risk.

Conclusion: The prevalence of malnutrition is high in neurology clinics. As malnutrition is frequently observed in patients with stroke, it is often identified in other neurologic diseases. Diabetes increases the risk of malnutrition. Physicians should be alert to hypoalbuminemia, higher creatinine, and CRP levels.
\end{abstract}

Keywords: Malnutrition, neurology, laboratory

$\ddot{O} \mathbf{z}$

Amaç: Hastane yatışlarında malnütrisyon yüksek oranlarda saptanmakta, hastaların morbidite ve mortalitelerine etki etmektedir. Çalışmamız hastaneye yatışta malnütrisyon riskini belirlemek, ilişkili komorbiditeler ve laboratuvar parametrelerini saptamak amacıyla planlanmıştır.

Gereç ve Yöntem: Çalışmaya nöroloji kliniğimize Haziran 2016-Ocak 2018 tarihleri arasında yatan tüm hastalar alındı. Hastaların yaşları, cinsiyetleri, tanıları ve komorbiditeleri kaydedildi. Kreatinin, albümin, lenfosit, C-reaktif protein (CRP) ve lipid profili çalışıldı. Malnütrisyon riski 65 yaş üstü hastalar için mini nütrisyonel değerlendirme, 65 yaş altı için Nutrition Screening 2002 testleri kullanılarak hesaplandı.

Bulgular: Çalışmaya 728 hasta alındı. Hastaların $\% 45,5^{\prime}$ i kadındı ve yaş ortalaması $61,54 \pm 16,96$ idi. Hastaların $\% 68,4^{\prime}$ ünde iskemik inme, \%8'inde demyelinizan hastalık, \%5,6'sında hemorajik inme, \%4,3'ünde santral sinir sistemi (SSS) enfeksiyonu, \%3,8'inde hareket bozuklukları, \%2,7'sinde polinöropati, $\% 1,8$ 'inde epilepsi, \%1,6'sında psödotümör serebri, \%1,2'sinde kraniyal nöropati, \%1'inde demans, \%0,6'sinda metabolik bozukluk ve \%0,7'sinde miyasteni tespit edildi. En sık saptanan komorbidite hiperlipidemiydi. Yedi yüz yirmi sekiz hastanın \%28,4’ünde başvuruda malnütrisyon riski tespit edildi. Tüm inmeli hastaların \%30’unda malnütrisyon riski mevcuttu. Malnütrisyon riski, SSS enfeksiyonu olan hastalarda \%19, hareket bozukluğu olan hastalarda \%32, polinöropatili hastalarda $\% 25$, demyelinizan hastalık tanılı hastalarda \%24, psödotümör serebri tanılı hastalarda \%0,8, epilepsili hastalarda $\% 15$ idi. Diabetes mellitus malnütrisyon riski ile anlamlı olarak ilişkiliydi. Albümin düşüklügüü, CRP ve kreatinin yüksekliği malnütrisyon riski ile anlamlı ilişkiliydi.

Sonuç: Malnütrisyon prevalansı nöroloji kliniklerinde yüksek oranlardadır. En çok inmeli hastalarda saptanmasına karşın diğer nörolojik hastalıklarda da gözlemlenmiştir. Diyabetin varlığı malnütrisyon riskini artırır. Albümin düşüklüğü, kreatinin ve CRP yüksekliği klinisyeni malnütrisyon açısından uyarmalıdır. Anahtar Kelimeler: Malnütrisyon, nöroloji, laboratuvar

The study was presented as a controversial poster at the $54^{\text {th }}$ National Neurology Congress.

Address for Correspondence/Yazışma Adresi: Eda Çoban MD Assoc. Prof., University of Health Sciences Turkey, Bagcilar Training and Research Hospital, Clinic of Neurology, Istanbul, Turkey

Phone: +90 5054834377 E-mail: eda_coban@yahoo.com ORCID: orcid.org/0000-0001-5894-7318

Received/Geliş Tarihi: 03.01 .2020 Accepted/Kabul Tarihi: 01.11 .2020

${ }^{\circ}$ Copyright 2021 by Turkish Neurological Society

Turkish Journal of Neurology published by Galenos Publishing House. 


\section{Introduction}

Nutrition plays an important role in life and medicine. Malnutrition is a condition that causes impairment in body structure and functions as a result of insufficient and unbalanced intake of nutrients such as energy and protein. Therefore, it is an important problem especially in hospitals and nursing homes (1). Malnutrition is also important because it is common in patients with chronic and serious diseases, it increases morbidity and mortality, and decreases the quality of life. However, the lack of knowledge of the healthcare personnel about malnutrition prevents diagnosis of malnutrition and this causes nutritional deficiency to be frequently overlooked during hospitalizations (1). However, with the early detection of malnutrition and timely initiation of nutritional support, the rate of malnutrition and its costs in hospitals can be reduced and the hospitalization period of the patients can be shortened.

Our study was planned to determine the frequency of malnutrition in neurology, to determine the relationship between comorbidities and malnutrition, and to determine parameters that could be used as malnutrition predictors.

\section{Materials and Methods}

All patients hospitalized in our hospital's neurology clinic between June 2016 and January 2018 were included in the prospectively planned study. The current neurologic diagnoses of the patients were recorded. Age, sex, and accompanying comorbid diseases were questioned. C-reactive protein (CRP), serum albumin, serum creatinine, lipid profile, and serum lymphocyte count were measured within the first 24 hours after hospitalization.

Blood pressure (BP) measurements of the patients were made on the right arm after resting for at least 10 minutes with the arenoid manometer in a sitting position, with the arm at heart level. Persons with a BP of $140 / 90 \mathrm{mmHg}$ or above or patients who received antihypertensive treatment were considered as having hypertension.

Patients with fasting plasma glucose $126 \mathrm{mg} / \mathrm{dl}$, patients with coincidental plasma glucose level $\geq 200 \mathrm{mg} / \mathrm{dl}$ with diabetic symptoms, patients with glycated hemoglobin (HbA1c) level $\geq 6.5 \%$, and patients who were diagnosed as having diabetes or who were using antidiabetic drugs were considered as having diabetes.

The diagnosis of hyperlipidemia was based on the classification of lipid levels according to the National Cholesterol Education Program/Adult Treatment Panel (NCEP ATP III) Guideline. Accordingly, patients with low-density lipoprotein cholesterol $>100 \mathrm{mg} / \mathrm{dl}$, total cholesterol $>200 \mathrm{mg} / \mathrm{dl}$, triglycerides $>150$ $\mathrm{mg} / \mathrm{dl}$ or patients who were receiving antilipidemic therapy were considered as having hyperlipidemia.

The nutritional status of the patients was evaluated within 1-3 days following their hospitalization. The Mini Nutritional Assessment (MNA) test was used for patients aged over 65 years and the Nutrition Risk Screening 2002 (NRS 2002) test was used for patients aged under 65 years to assess nutritional status.

In the MNA test, which is recommended as the most appropriate assessment method for the elderly, there are six parts in which general eating habits of patients (such as how many meals a day they eat, how many glasses of liquid they consume, how many portions of fruit they eat), subjective factors (neuropsychological problems), and weight and height are questioned. The maximum score is 14 points and $\leq 11$ points are considered as having malnutrition risk (2).

The NRS 2002, as recommended by the European Society for Parenteral and Enteral Nutrition is a screening test that evaluates the adequacy of nutritional support, especially in the case of acute illness. The test was developed for all hospitalized patients (old and young), not older patients. The first part evaluates the nutritional history of the patient (e.g. difficulty in swallowing and chewing, nausea, presence of gas, constipation, diarrhea). The second part consists of two parts reflecting the severity of the disease and increased nutritional requirement. If the score is 3 , the patient is at nutritional risk $(3,4)$.

The study was approved by Bakirkoy Education and Training Hospital of Neurology, Neurosurgery and Psychiatry's Clinical Ethics Research Committee (number: 6638, date: 18.02.2019).

All the patients involved in the study provided written informed consent.

\section{Statistical Analysis}

The difference between the groups was investigated using the chi-square test and multiple regression analysis was used in the analysis of comorbidities affecting malnutrition. A p value $<0.05$ was accepted as statistically significant. Statistical analyses were performed using the SPSS Statistics 17.0 program. Descriptive analyses (numbers and rates) are shown in the tables.

\section{Results}

A total of 728 neurology patients were included in the study during an 18-month follow-up. Of the patients, 331 were female and $397(54.5 \%)$ were male. Their mean age was $61.54 \pm 16.96$ years. The demographic characteristics and neurologic diagnoses of the patients are given in Table 1 . The most common diagnosis was ischemic stroke $(68.4 \%)$. Demyelinating disease was found in $7.9 \%$ and hemorrhagic stroke in $5.6 \%$ of the patients. As can be seen in Table 1, 6 of the 728 patients were hospitalized secondary to hyponatremia or metabolic disorder due to hypoglycemia.

Hyperlipidemia was the most common accompanying comorbid disease in $71.2 \%$ of the patients. Hypertension (47.9\%), diabetes $(28.7 \%)$, history of stroke $(12.6 \%)$, dementia $(3.2 \%)$, and cancer $(1.8 \%)$ were other accompanying comorbid diseases (Table 1).

Malnutrition risk was detected in $28.4 \%$ of 728 patients at the time of hospitalization. Malnutrition risk was found in $30 \%$ of all patients with stroke at the time of admission. There was a risk of malnutrition in $30.7 \%$ of patients who had ischemic stroke and $26.8 \%$ of those who had hemorrhagic stroke. There was a risk of malnutrition in $42.8 \%$ of patients with dementia, $19 \%$ of patients with central nervous system infection, $32 \%$ of those with movement disorders, $25 \%$ of those with polyneuropathy (acute/chronic), and $24 \%$ of those with demyelinating disease. Malnutrition risk was found in $0.8 \%$ of patients with pseudotumor cerebri and $15 \%$ of patients with epilepsy (Table 1 ).

It was observed that the presence of diabetes posed a statistically significant risk in terms of malnutrition risk $(\mathrm{p}=0.02)$.

Among the laboratory parameters examined in the patients, lower albumin, higher CRP, and higher creatinine levels were observed to be related to the risk of malnutrition $(\mathrm{p}=0.002$, $\mathrm{p}<0.001$, and $\mathrm{p}=0.02$, respectively) (Table 2). 
Table 1. Demographic characteristics, comorbidities, neurologic disease diagnoses, and malnutrition risk of the patients

\begin{tabular}{|c|c|c|c|}
\hline Demographic characteristics & Percentage of patients $(\%)$ & Malnutrition risk (\%) & $\mathrm{p}$ value \\
\hline Age & $61.54 \pm 16.96$ & - & - \\
\hline Male sex & 54.5 & $17 \%$ & $>0.05$ \\
\hline \multicolumn{4}{|l|}{ Comorbid diseases } \\
\hline $\begin{array}{l}\text { Hyperlipidemia } \\
\text { Hypertension } \\
\text { Diabetes mellitus } \\
\text { Coronary artery disease } \\
\text { Chronic kidney failure } \\
\text { History of stroke } \\
\text { Atrial fibrillation } \\
\text { Dementia } \\
\text { Presence of cancer }\end{array}$ & $\begin{array}{l}71.2 \\
47.9 \\
28.7 \\
15.5 \\
14.3 \\
12.6 \\
10 \\
3.2 \\
1.8\end{array}$ & $\begin{array}{l}28 \% \\
31 \% \\
34 \% \\
30 \% \\
26 \% \\
30 \% \\
36 \% \\
17 \% \\
23 \%\end{array}$ & $\begin{array}{l}>0.05 \\
>0.05 \\
0.02 \\
>0.05 \\
>0.05 \\
>0.05 \\
>0.05 \\
>0.05 \\
>0.05\end{array}$ \\
\hline \multicolumn{4}{|l|}{ Diagnosis of neurologic disease } \\
\hline $\begin{array}{l}\text { Ischemic stroke } \\
\text { Demyelinating disease } \\
\text { Hemorrhagic stroke } \\
\text { CNS infection } \\
\text { Movement disorders } \\
\text { Polyneuropathy (acute/chronic) } \\
\text { Epilepsy } \\
\text { Pseudotumor cerebri } \\
\text { Cranial neuropathy } \\
\text { Dementia } \\
\text { Metabolic disorder } \\
\text { Myasthenia gravis (bulbar/generalized) }\end{array}$ & $\begin{array}{l}68.4 \\
8 \\
5.6 \\
4.3 \\
3.8 \\
2.7 \\
1.8 \\
1.6 \\
1.2 \\
1 \\
0.8 \\
0.7\end{array}$ & $\begin{array}{l}30.7 \% \\
24 \% \\
26.8 \% \\
19 \% \\
32 \% \\
25 \% \\
15 \% \\
0.8 \% \\
11 \% \\
42.8 \% \\
17 \% \\
2 \%\end{array}$ & $\begin{array}{l}- \\
- \\
- \\
- \\
- \\
- \\
- \\
- \\
- \\
- \\
-\end{array}$ \\
\hline
\end{tabular}

Table 2. Detection rates of laboratory tests in the patients

\begin{tabular}{lll|} 
Laboratory parameters & $(\%)$ & p value \\
Low albumin & $8.7 \%$ & 0.002 \\
High creatinine & $1.9 \%$ & 0.02 \\
High C-reactive protein & $51.4 \%$ & $<0.001$ \\
Lymphopenia & $14.1 \%$ & 0.1 \\
High total cholesterol & $36 \%$ & 0.13 \\
High triglyceride & $33.7 \%$ & 0.34 \\
High LDL & $59.2 \%$ & 0.17 \\
Low HDL & $47.4 \%$ & 0.59 \\
LDL: Low-density lipoprotein, HDL: High-density lipoprotein & \\
\hline
\end{tabular}

\section{Discussion}

Malnutrition is an independent risk factor that increases mortality and morbidity with complications (wound healing, increased susceptibility to infections) during the patient's hospitalization, increases the duration of hospitalization and recovery, increases the cost, and causes re-hospitalization. Although the disease itself causes malnutrition, the lack of knowledge of staff about the patient's nutritional status, the absence of standard nutritional protocols established in the hospital, and the inability to identify patients at risk are among the factors that predispose to malnutrition (5).
In our study, malnutrition risk was detected in $28.4 \%$ of our patients at the time of hospitalization. Different malnutrition rates were found in studies conducted in Europe, the United States of America, and Australia. Different medical and geographic conditions, different patient populations, and the variety of tests used to detect malnutrition were the most important reasons for this discrepancy (6). In a study including 29,139 patients from 34 hospitals in 19 provinces in Turkey, the rate of patients at risk of malnutrition at admission was found as $15 \%$ (7). Of the patients hospitalized, $76 \%$ were patients with cerebrovascular diseases because our hospital is a comprehensive stroke center. Of the patients with cerebrovascular diseases, $68.4 \%$ had ischemic stroke. Therefore, in our patient profile, the risk of malnutrition was mostly observed in patients with stroke (in $30.7 \%$ of patients with ischemic stroke and $26.8 \%$ of patients with hemorrhagic stroke). The prevalence of malnutrition after stroke in the literature differs from study to study. It is estimated that onefifth of patients with acute stroke are malnourished at the time of admission (8). The presence of chronic concomitant diseases, polypharmacy, eating difficulties, and functional disability have been found to be associated with malnutrition, especially in older patients (9). Diabetes mellitus and history of stroke increased the risk of malnutrition at the time of admission at rates of $58 \%$ and $71 \%$, respectively; the type and location of stroke, paresis of dominant extremity, socioeconomic status, and education were not found to be associated with malnutrition risk $(10,11)$. In our study, 
it was observed that the presence of diabetes posed a statistically significant risk in terms of malnutrition risk.

The prevalence of malnutrition has been studied in very few patients with multiple sclerosis (MS) to date. There are studies showing that malnutrition is associated with MS. Sorgun et al. (12) identified malnutrition in 12 of 100 patients with MS in Turkey. Of our patients with demyelinating disease, $24 \%$ were at risk of malnutrition at the time of hospitalization. Sorgun et al. (12) could not show that the type of MS, duration of disease, number of attacks, Expanded Disability Status Scale score or Functional Sytems Score were associated with the presence of malnutrition.

Similarly, malnutrition was found at significant rates in patients with other neurologic diseases who were hospitalized in our clinic. Malnutrition risk was found in 5 of 7 patients with dementia at admission. Although this rate $(42.8 \%)$ seemed to be the highest rate found in the literature, these patients constituted a very small majority of the existing patients. With a higher number of patients, more reliable data can be obtained. Also, the risk of malnutrition in the elderly with dementia was found at $37.3 \%$ in a study by Ülger et al. (13) from Turkey. Malnutrition risk was detected in $32 \%$ of our patients hospitalized with a diagnosis of movement disorder. The rate of malnutrition found in the literature in patients with Parkinson's disease varies between 0 and $25.5 \%$, but the rate of patients at risk of malnutrition rises to $34.3 \%$ (14). On the other hand, $0.8 \%$ of the patients with pseudotumor cerebri had a risk of malnutrition in our study. Although pseudotumor cerebri is a condition associated with obesity, it does equate to adequate nutrition. In the literature, no study determining the risk of malnutrition in such patients has been found. This result may be a reflection of the high risk of malnutrition in the general population. Nutritional studies to be performed in patients with pseudotumor cerebri by increasing the number of patients may shed light on the risk of malnutrition in those patients in the future.

According to meta-analysis results, many laboratory parameters such as albumin, prealbumin, hemoglobin, total cholesterol and total protein are used as malnutrition predictors even in the presence of chronic inflammation (15). The most studied protein in the diagnosis of malnutrition is albumin. CRP, and total lymphocyte and leukocyte counts are parameters that also reflect inflammation, as such they may not be good markers in the assessment of nutritional status. Transferrin, creatinine, total triglyceride, iron, and hematocrit are not sufficient in determining the risk of malnutrition. However, many studies in the literature found that 17 laboratory parameters including albumin, prealbumin, total protein, hemoglobin, and low total cholesterol were associated with the risk of malnutrition (16). In our study, lower albumin, higher CRP, and higher creatinine levels were found in patients with malnutrition risk. In light of all these studies, although laboratory parameters are useful in detecting malnutrition, it is not possible to say that a patient has malnutrition based on any one of these parameters alone. Laboratory findings should be supportive in clinical practice and complement physical examination findings and malnutrition scales.

\section{Study Limitations}

There were some limitations in our study. Most of the hospitalized patients had stroke because our hospital is a stroke center. Therefore, in our study, there was no homogeneous distribution among neurologic diseases. Also, because our hospital was also a branch hospital, it was not possible to compare the malnutrition rate in our patients with the rates in other patients hospitalized in different clinics. Nevertheless, our results were compatible with the literature and suggestive in terms of instigating new studies.

\section{Conclusion}

As a result, the risk of malnutrition was high, even at the time of admission in neurology clinics. The existing comorbidities of patients, especially the presence of diabetes, may be associated with the risk of malnutrition. Similarly, it was shown in our study that among laboratory parameters, lower albumin, higher CRP, and higher creatinine levels were found in patients at risk of malnutrition. It should be our goal to establish hospital protocols to detect the presence of malnutrition early, which may negatively affect the clinical course of patients, and to make use of nutritional scales at the time of hospitalization as a part of medical treatment.

\section{Ethics}

Ethics Committee Approval: The study was approved by Bakirkoy Education and Training Hospital of Neurology, Neurosurgery and Psychiatry's Clinical Ethics Research Committee (number: 6638, date: 18.02.2019).

Informed Consent: All the patients involved in the study provided written informed consent.

Peer-review: Externally and internally peer-reviewed.

\section{Authorship Contributions}

Concept: E.Ç., A.S., Design: E.Ç., A.S., Data Collection or Processing: E.Ç., Analysis or Interpretation: E.Ç., Literature Search: E.Ç., Writing: E.Ç.

Conflict of Interest: No conflict of interest was declared by the authors.

Financial Disclosure: The authors declared that this study received no financial support.

\section{References}

1. Yılmaz KD, Sarkut P, Düzgün P, Kuzu C, Kilıçturgay S. The Views of Nurses on Nutritional Assessment and Nutritional Support of Hospitalized Patients. Hemşirelikte Ĕ̆itim ve Araştırma Dergisi 2017;14:139-143.

2. Guigoz Y, Lauque S, Vellas BJ. Identifying the elderly at risk for malnutrition. The mini nutritional assessment. Clin Geriatr Med 2002;18:737-756.

3. Kondrup J, Allison SP, Elia M, Vellas B, Plauth M. ESPEN guidelines for nutrition screening 2002. Clin Nutr 2003;22:415-421.

4. Kondrup J, Rasmussen $\mathrm{HH}$, Hamberg O, Stanga Z. Nutritional risk screening (NRS 2002): a new method based on an analysis of controlled clinical trials. Clin Nutr 2003;22:321-336.

5. Löser C. Malnutrition in hospital: the clinical and economic implications. Dtsch Arztebl Int 2010;107:911-917.

6. Krulzenga H, Van Keeken S, Weijs P, et al. Undernutrition screeningsurvey in 564,063 patients. Patients with a positive undernutrition screening score stay in hospital 1.4 d longer. Am L Clin Nutr 2016;103:1026-1032.

7. Korfalii G, Gündogdu H, Aydintg S, et al. Nutritional risk of hospitalized patients in Turkey. Clin Nutr 2009;28:533-537.

8. Sánchez-Moreno C, Jiménez-Escrig A, Martín A. Stroke: roles of B vitamins, homocysteine and antioxidants. Nutr Res Rev 2009;22:49-67.

9. Ha L, Hauge T, Iversen PO. Body composition in older acute stroke patients after treatment with individualized, nutritional supplementation while in hospital. BMC Geriatr 2010;10:75.

10. Corrigan ML, Escuro AA, Celestin J, et al. Nutrition in the stroke patient. Nutr Clin Pract 2011;26:242-252. 
11. Chai J, Chu FCS, Chow TW, et al. Prevalence of malnutrition and its risk factors in stroke patients residing in an infirmary. Singapore Med J 2008;49:290-296.

12. Sorgun MH, Yucesan C, Tegin C. 'Is Malnutrition a problem for multiple sclerosis patients?' J Clin Neurosci 2014;21:1603-1605.

13. Ülger Z, Halil M, Kalan I, et al. Comprehensive assessment of malnutrition risk and related factors in a large group of community-dwelling older adults. Clin Nutr 2010;29:507-511.

14. Fereshtehnejad SM, Ghazi L, Sadeghi M, et al. Prevalence of malnutrition in patients with Parkinson's disease: a comparative study with healthy control using Mini Nutritional Assessment (MNA) questionnaire. J Parkinsons Dis 2014; 4:473-481.

15. Raiten DJ, Namaste S, Brabin B, et al. Executive summary-biomarkers of nutrition for development: building a consensus. Am J Clin Nutr 2011;94:633S-650S.

16. Zhang Z, Pereira SL, Luo M, et al. Evaluation of blood biomarkers associated with risk of malnutrition in older adults: a systematic review and metaanalysis. Nutrients 2017;8:829. 